Review

\title{
Spectroscopic Investigation of the Mechanism of Photocatalysis
}

\author{
Yoshio Nosaka *, Masami Nishikawa and Atsuko Y. Nosaka \\ Nagaoka University of Technology, 1603-1 Kamitomioka, Nagaoka 940-2188, Japan; \\ E-Mails: nishikawa@nagaokaut.ac.jp (M.N.); aynosaka@mst.nagaokaut.ac.jp (A.Y.N.) \\ * Author to whom correspondence should be addressed; E-Mail: nosaka@nagaokaut.ac.jp; \\ Tel./Fax: +81-258-47-9315.
}

External Editor: Pierre Pichat

Received: 1 September 2014; in revised form: 21 October 2014 / Accepted: 27 October 2014/ Published: 7 November 2014

\begin{abstract}
Reaction mechanisms of various kinds of photocatalysts have been reviewed based on the recent reports, in which various spectroscopic techniques including luminol chemiluminescence photometry, fluorescence probe method, electron spin resonance (ESR), and nuclear magnetic resonance (NMR) spectroscopy were applied. The reaction mechanisms elucidated for bare and modified $\mathrm{TiO}_{2}$ were described individually. The modified visible light responsive $\mathrm{TiO}_{2}$ photocatalysts, i.e., $\mathrm{Fe}(\mathrm{III})$-deposited metal-doped $\mathrm{TiO}_{2}$ and platinum complex-deposited $\mathrm{TiO}_{2}$, were studied by detecting paramagnetic species with ESR, $\bullet \mathrm{O}_{2}{ }^{-}$ (or $\mathrm{H}_{2} \mathrm{O}_{2}$ ) with chemiluminescence photometry, and $\mathrm{OH}$ radicals with a fluorescence probe method. For bare $\mathrm{TiO}_{2}$, the difference in the oxidation mechanism for the different crystalline form was investigated by the fluorescence probe method, while the adsorption and decomposition behaviors of several amino acids and peptides were investigated by ${ }^{1}$ H-NMR spectroscopy.
\end{abstract}

Keywords: ESR; NMR; $\mathrm{OH}$ radical; superoxide radical; $\mathrm{H}_{2} \mathrm{O}_{2}$; acetaldehyde; metal doped $\mathrm{TiO}_{2}$; glutathione; amino acids; visible-light responsive photocatalysts

\section{Introduction}

$\mathrm{TiO}_{2}$ photocatalysts have been widely utilized for the oxidation of organic pollutants [1-4]. For further practical applications, the improvement in the photocatalytic efficiency and the extension of the effective wavelength to visible region are desired. To develop photocatalysts, understanding of the 
detailed photocatalytic mechanisms is prerequisite. Recently, the reaction mechanisms of $\mathrm{TiO}_{2}$ photocatalysis have been extensively reviewed [5] and the authors also reviewed the reports published up to 2011 from the view of the detection of active oxygen species [6]. In this manuscript, recent development in the reaction mechanism mainly reported by our group was reviewed. Main techniques used were ESR spectroscopy for the state of photoinduced electron and holes, fluorescence probe method for the formation of $\mathrm{OH}$ radical and NMR spectroscopy for the adsorption and decomposition of biological molecules in solution.

\section{Spectroscopic Methods for Investigating Photocatalysis}

\subsection{ESR (Electron Spin Resonance) Spectroscopy}

ESR spectroscopy is conventionally used to detect unpaired electrons. Photocatalytic reactions proceed by the two following reactions: reduction of reactants with photoexcited electrons and oxidation of reactants with holes. Therefore, it is important to examine the generation behavior of these active species. In $\mathrm{TiO}_{2}$ photocatalytic systems, two kinds of active species (photoexcited electron and hole) are generated on absorbing photons. Some of the electrons and holes are trapped at $\mathrm{Ti}$ and $\mathrm{O}$ atoms, to become $\mathrm{Ti}^{3+}$ and $\mathrm{O}^{-}$, respectively. Therefore, by detecting these trapped electrons and holes using ESR spectroscopy under light irradiation of different wavelengths, the generation behavior of excited species can be examined. Moreover, the electron transfer between photocatalysts and co-catalysts can be also examined because if the electron transfer occurs, the amount of the unpaired electron in the co-catalyst should change before and after light irradiation. Therefore, ESR spectroscopy is very useful to elucidate photocatalytic reaction mechanism.

\subsection{Chemiluminescence Photometry}

Reduced oxygen molecules such as superoxide radical $\left(\cdot{ }^{-} \mathrm{O}_{2}^{-}\right)$and $\mathrm{H}_{2} \mathrm{O}_{2}$ can be detected by chemiluminescence with luminol ( $\mathrm{LH}_{2}$, aminodiazabenzoquinone). The one electron oxidized state of luminol $\left(\cdot \mathrm{L}^{-}\right)$reacts with $\cdot \mathrm{O}_{2}{ }^{-}$to form the excited state of 3-aminophthalic acid to emit fluorescence in alkaline solution [7], where $\cdot \mathrm{L}^{-}$is formed from $\mathrm{LH}_{2}$ by the oxidation with $\bullet \mathrm{O}_{2}{ }^{-}$[8]. Since $\bullet \mathrm{O}_{2}{ }^{-}$is rather stable in alkaline solution, after the irradiation on photocatalyst was stopped, luminol is injected to measure the amount of $\cdot \mathrm{O}_{2}{ }^{-}$by the chemiluminescence intensity. The same chemiluminescence was obtained from $\mathrm{H}_{2} \mathrm{O}_{2}$ by the reaction with $\mathrm{L}$ that is two-electron oxidized state of $\mathrm{LH}_{2}$ [9]. To measure the amount of $\mathrm{H}_{2} \mathrm{O}_{2}$ in solution, after mixing luminol, hemoglobin was added to oxidize luminol, because $\mathrm{L}$ is rather unstable [8]. Luminol chemiluminescence method has some problems. It is available only in alkaline solution, and luminol emits light with $\mathrm{SiO}_{2}$ in the absence of $\bullet \mathrm{O}_{2}{ }^{-}$and $\mathrm{H}_{2} \mathrm{O}_{2}$. Therefore, in the case of $\mathrm{SiO}_{2}$ deposited $\mathrm{TiO}_{2}$, instead of luminol, MCLA and lucigenin were employed for the detection of $\cdot \mathrm{O}_{2}{ }^{-}$and $\mathrm{H}_{2} \mathrm{O}_{2}$, respectively, by means of chemiluminescence photometry [10].

\subsection{Florescence Probe Method}

Hydroxyl radical $(\bullet \mathrm{OH})$ has been recognized as a key active species in the oxidation mechanism in photocatalysis $[9,11]$. For the detection of $\bullet \mathrm{OH}$ we employed coumarin. It reacts with $\bullet \mathrm{OH}$ to produce 7-OH coumarin (umbelliferone) which emits strong fluorescence [12]. After the irradiation of a coumarin 
aqueous solution containing photocatalysts powder for a given time, the fluorescence intensity of the fluorescent products (umbelliferone) in the solution was measured. The $\cdot \mathrm{OH}$ concentration could be calculated from the concentration of umbelliferone with the aid of data of radiation chemistry [12]. Since carboxyl group is known to adsorb on $\mathrm{TiO}_{2}$, the similar experiments were performed for 3 -carboxylic acid derivative of coumarin (CCA, Figure 1), and ensured the reaction with $\bullet \mathrm{OH}$ to form $\mathrm{OH}-\mathrm{CCA}$ as illustrated in Figure 1 [13].

Figure 1. Probing reaction of $\mathrm{OH}$ radical with $\mathrm{CCA}$ (coumarin 3-carboxy acid) to form fluorescent molecule $\mathrm{OH}-\mathrm{CCA}$ (7-hydroxy coumarin 3-carboxy acid).<smiles>Cc1ccc2cc(C(=O)O)c(=O)oc2c1</smiles>

\section{CCA}

\section{$\mathrm{OH}-\mathrm{CCA}$}

\subsection{NMR (Nuclear Magnetic Resonance) Spectroscopy}

${ }^{1} \mathrm{H}-\mathrm{NMR}$ spectroscopy has been recognized as an effective technique to investigate the behaviors of the reactant molecules in the photocatalytic systems. The adsorption and the decomposition of biomolecules such as amino acids and peptides in the aqueous suspension of photocatalysts can be investigated with ${ }^{1} \mathrm{H}-\mathrm{NMR}$ spectroscopy with relatively feasible experimental procedures [14] as follows. Firstly, ${ }^{1} \mathrm{H}-\mathrm{NMR}$ of organic molecules dissolved in the solvent are measured. Then certain amount of the photocatalysts is added to the solution. From the initial decrease in the intensity of ${ }^{1} \mathrm{H}-\mathrm{NMR}$ peaks of the corresponding reactant molecules the amount of the adsorption can be estimated. Then, by measuring the decrease in the intensities of reactant molecules for various photoirradiation times, one could estimate the photodecomposition rates of the reactants [15].

\section{Mechanism of Photocatalysis}

\subsection{Bare-TiO ${ }_{2}$ and Visible-Light Responsive $\mathrm{TiO}_{2}$ Photocatalysts}

General scheme of photocatalysis applied for the oxidation of pollutant is shown in Figure 2. Light absorption in semiconductor corresponds to the formation of an electron $\left(\mathrm{e}^{-}\right)$in the conduction band (CB) and a hole $\left(\mathrm{h}^{+}\right)$in the valence band (VB). Usually $\mathrm{e}^{-}$reduces $\mathrm{O}_{2}$ in air to form ${ }^{\cdot} \mathrm{O}_{2}{ }^{-}$and $\mathrm{H}_{2} \mathrm{O}_{2}$.

The photocatalytic oxidation of organic compounds is accelerated with oxygen [16]. The consumption of $\mathrm{O}_{2}$ at the oxidation site of the photocatalyst has been suggested from the experiment of electrochemical probe reactions at the surface of illuminated $\mathrm{TiO}_{2}$ photoelectrode [17]. Therefore, the generalized oxidation mechanism of organic molecules (RH) can be illustrated as shown in Figure 2. Organic reactants $\mathrm{RH}$ will degrade by losing one carbon atom by releasing $\mathrm{CO}_{2}$ through the intermediates like aldehyde $\mathrm{R}^{\prime} \mathrm{CHO}$ or carboxylate $\mathrm{R}^{\prime} \mathrm{COO}^{-}$. Although $\bullet \mathrm{OH}$ has been often regarded to play an important role in the actual oxidation mechanism of photocatalytic reactions, $\bullet \mathrm{OH}$ is not 
involved in the main oxidation process for organic compounds. In place of it, the surface trapped holes play the role of oxidation, which may be acknowledged as the surface adsorbed $\bullet \mathrm{OH}$ in the de-protonated form as stated below.

Figure 2. General reaction processes for the photocatalytic oxidation of organic molecules.

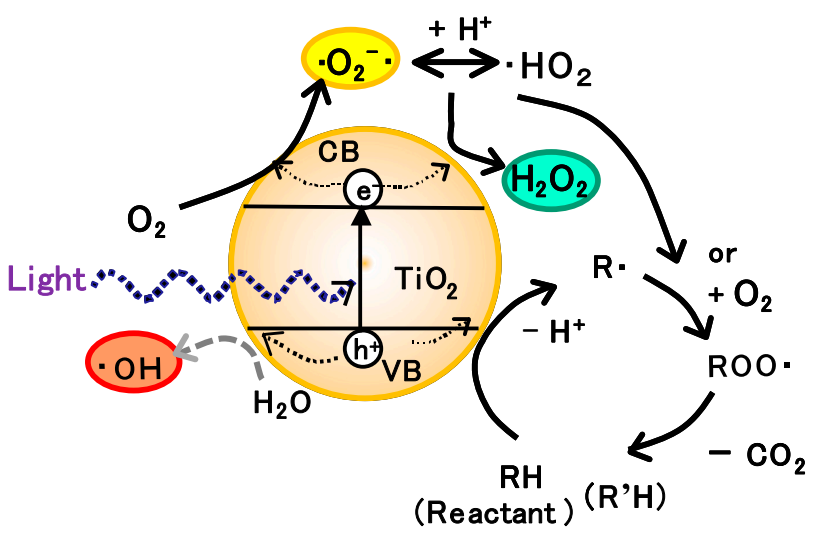

For the extension of the practical applications of photocatalysts, the utilization of visible light has been intensively promoted. Figure 3 shows the energy levels of several representative visible-light responsive photocatalysts. Since the one-electron reduction potential of $\mathrm{O}_{2}$ is very close to that of the CB bottom of $\mathrm{TiO}_{2}$ and the energy level of VB has sufficient oxidation ability, the shift of the VB by doping $\mathrm{N}$ (or, $\mathrm{C}$ and $\mathrm{S}$ ) anions has been attempted to absorb visible light (b). In this case, photogenerated holes at the donor level should have the oxidation ability similarly to that of bare $\mathrm{TiO}_{2}$ [9].

Figure 3. Classification of visible-responsive photocatalysts by the primary reaction mechanism. (a) Unmodified $\mathrm{TiO}_{2}$; (b) Nitrogen doped $\mathrm{TiO}_{2}$; (c) $\mathrm{Fe}(\mathrm{III})$ grafted $\mathrm{TiO}_{2}$; (d) $\mathrm{Fe}$ (III) grafted metal doped $\mathrm{TiO}_{2}$; (e) Platinum complex deposited $\mathrm{TiO}_{2}$. Adopted with permission from [18]. (C) 2013 American Chemical Society.

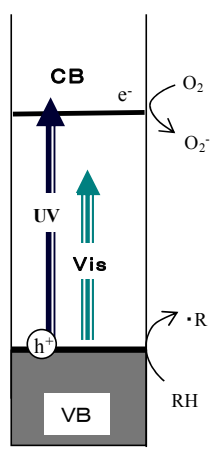

(a) $\mathrm{TiO}_{2}$

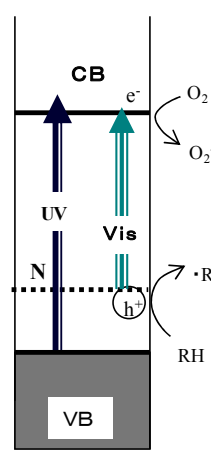

(b) $\mathrm{N}-\mathrm{TiO}_{2}$

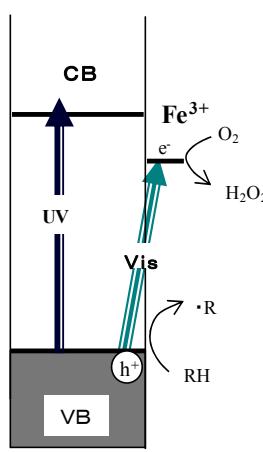

(c) $\mathrm{Fe}$ (III) $/ \mathrm{TiO}_{2}$

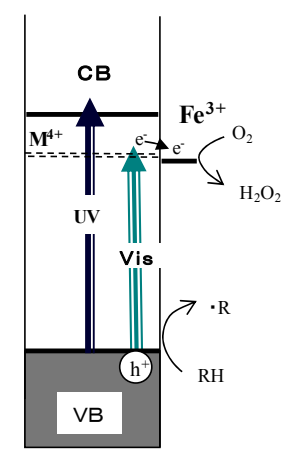

(d)Fe ( III) / $\mathrm{M:TiO}$

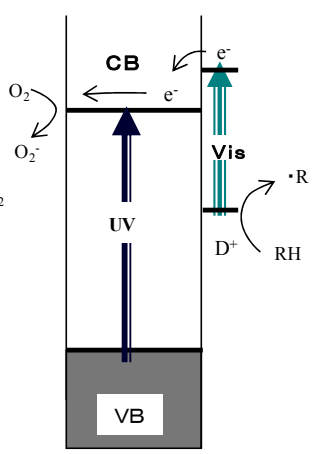

(e)PtCl/ $\mathrm{TiO}_{2}$

Recently, interfacial charge transfer (IFCT) type absorption originating from the excitation of VB electrons to deposited (or grafted) metal ions has been proposed (c). In this case, if the deposited compound has a catalytic ability of $\mathrm{O}_{2}$ reduction, the efficiency is expected to be increased $[19,20]$. Since the absorbance of IFCT is very small, to increase the absorption, the transferring of the excited electron to the graft level by doping of metal ions was proposed (d). Photocatalysts of 
photosensitization type were also proposed, in which the stable metal complex such as $\mathrm{PtCl}_{6}^{2-}$ is deposited as a sensitizer (e). The deposited compound absorbs the visible light and transfers the excited electron to produce a cation radical $\mathrm{D}^{+}$, which can oxidize organic pollutant molecules. In this case, the enough oxidation power with good stability is required for the oxidized sensitizer $\mathrm{D}^{+}[21,22]$. To confirm the suggested reaction mechanism, several spectroscopic methods have been applied to the detection of the paramagnetic species produced on the catalysts along with the primary products $\left(\cdot \mathrm{O}_{2}{ }^{-}\right.$, $\left.\mathrm{H}_{2} \mathrm{O}_{2}, \cdot \mathrm{OH}\right)$.

\subsubsection{Fe(III) Grafted $\mathrm{TiO}_{2}$ Based Photocatalysts}

$\mathrm{Fe}(\mathrm{III})$ grafted $\mathrm{TiO}_{2}\left(\mathrm{Fe} / \mathrm{TiO}_{2}\right)$ showed the photocatalytic activity under visible light irradiation. The quantum efficiency of $\mathrm{Fe} / \mathrm{TiO}_{2}$ prepared under optimized condition was reported to be $22 \%$ [20]. We examined the photocatalytic reaction mechanism of the $\mathrm{Fe} / \mathrm{TiO}_{2}$ using ESR spectroscopy [23]. As shown in Figure 4A, under visible light irradiation, the ESR signal assigned to $\mathrm{Fe}^{3+}(\mathrm{g}=4.3)$ was decreased and the ESR signal assigned to trapped holes $(\mathrm{g}=2.01)$ at the $\mathrm{TiO}_{2}$ host was observed. In the case of $\mathrm{TiO}_{2}$ without the grafting of $\mathrm{Fe}^{3+}$, the trapped hole signal was scarcely observed as compared to the $\mathrm{Fe} / \mathrm{TiO}_{2}$ under visible light irradiation. This means that electrons at VB are directly transferred to the grafted $\mathrm{Fe}^{3+}$ rather than $\mathrm{CB}$ (Figure 4B). Using ESR spectroscopy, we could reveal for the first time that the direct electron transfer from the $\mathrm{VB}$ of $\mathrm{TiO}_{2}$ to the $\mathrm{Fe}^{3+}$ is the origin of the visible light response.

Figure 4. (A) ESR spectra of (a) $\mathrm{Fe}^{3+}$ and (b) holes for $\mathrm{Fe} / \mathrm{TiO}_{2}$ and (c) holes for $\mathrm{TiO}_{2}$ before and after light irradiation with different wavelengths; (B) Photocatalytic reaction mechanism for $\mathrm{Fe} / \mathrm{TiO}_{2}$ under visible light irradiation. Reprinted with permission from [23]. (C) 2012 American Chemical Society.
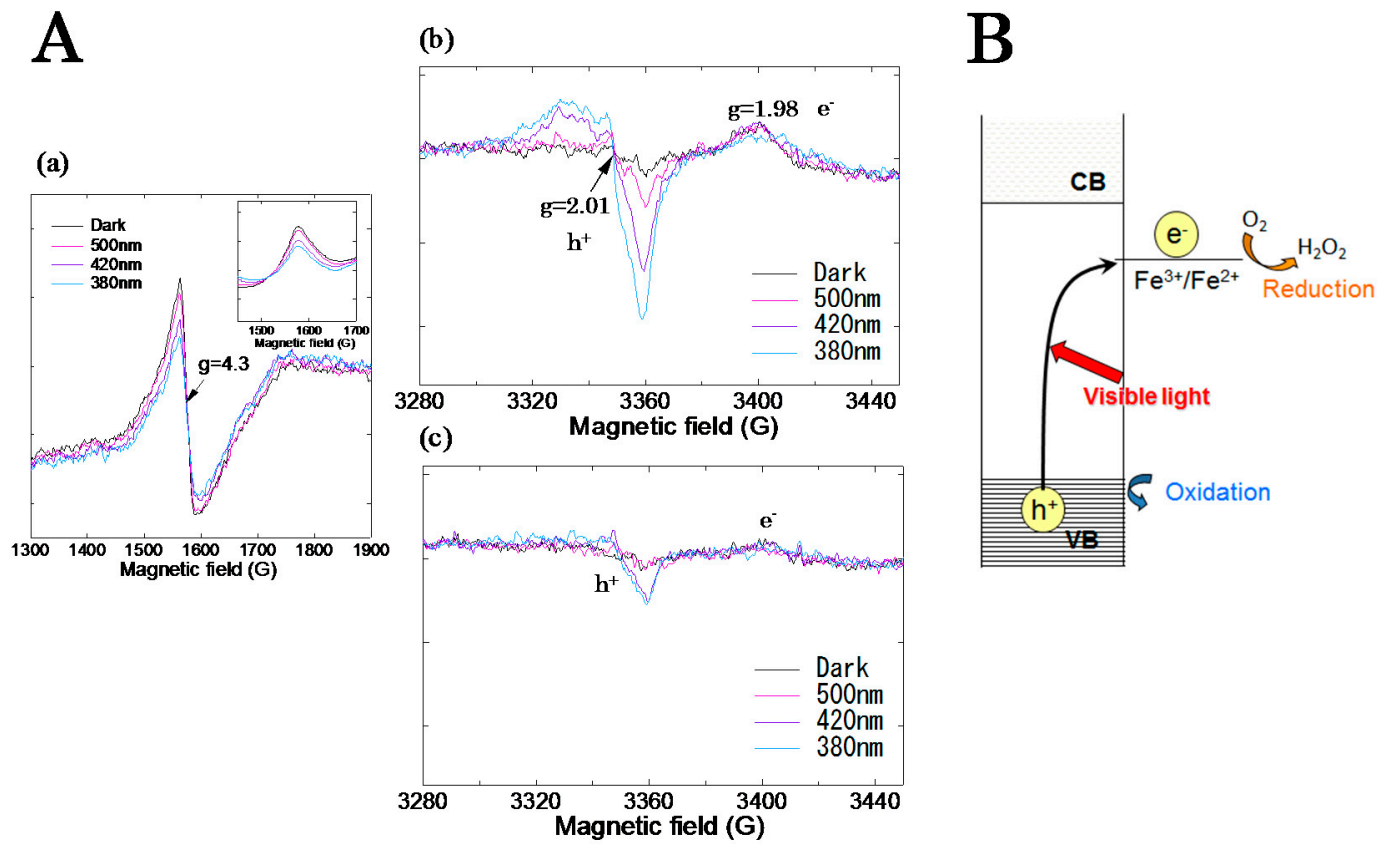

Photocatalytic reactions cannot proceed when the photogenerated electrons do not react with molecular oxygen, which is the only molecule to be reduced in ambient atmosphere even though the 
redox potential of the photogenerated hole is positive enough to decompose organic compounds. Therefore, it is important to confirm the reduction of $\mathrm{O}_{2}$ into $\cdot \mathrm{O}_{2}{ }^{-}$by one-electron or $\mathrm{H}_{2} \mathrm{O}_{2}$ by two-electron reductions. Under visible light irradiation, for $\mathrm{Fe} / \mathrm{TiO}_{2}$, the production of $\mathrm{H}_{2} \mathrm{O}_{2}$ was dominant as compared to $\cdot \mathrm{O}_{2}{ }^{-}$. This means that the excited $\mathrm{Fe}^{2+}$ can reduce $\mathrm{O}_{2}$ to $\mathrm{H}_{2} \mathrm{O}_{2}$ through two-electron process. Since the electrons having a potential energy of $+0.695 \mathrm{~V}\left(v_{s}\right.$. SHE at $\left.\mathrm{pH}=0\right)$ can reduce $\mathrm{O}_{2}$ to $\mathrm{H}_{2} \mathrm{O}_{2}$ by two-electron process [24], the redox potential of the grafted $\mathrm{Fe}^{3+}$ to $\mathrm{Fe}^{2+}$ was equal to or less than $+0.695 \mathrm{~V}(v s$. SHE at $\mathrm{pH}=0)$. Since photogenerated electrons were consumed by the reduction of $\mathrm{O}_{2}$ to $\mathrm{H}_{2} \mathrm{O}_{2}$, holes remained at valence band could decompose organic substances efficiently, resulting in the high performance.

Moreover, after the grafting of $\mathrm{Fe}^{3+}$ on the $\mathrm{TiO}_{2}$ doped with metal (M) ions such as $\mathrm{Ru}, \mathrm{Ir}, \mathrm{Rh}$ or $\mathrm{Cr}$ ions $\left(\mathrm{Fe} / \mathrm{M}: \mathrm{TiO}_{2}\right)$, the photocatalytic activities were enhanced compared to the $\mathrm{Fe} / \mathrm{TiO}_{2}$ as shown in Figure 5A. The visible light response was increased in the order $\mathrm{Ir}>\mathrm{Cr}>\mathrm{Ru}>\mathrm{Rh}$. In the case of the $\mathrm{Fe} / \mathrm{Ru}: \mathrm{TiO}_{2}$, based on the measurements by ESR spectroscopy, Ru ions were doped as tetravalent and played a role as an acceptor level. Then, the photoexcited Ru ions, by receiving electrons from the VB, immediately transfer electrons to the grafted $\mathrm{Fe}^{3+}$ under visible light irradiation. This indirect electron transfer from the $\mathrm{VB}$ to the $\mathrm{Fe}^{3+}$ via the doped $\mathrm{Ru}$ ions occurred in addition to the direct electron transfer from the VB to the $\mathrm{Fe}^{3+}$, leading to the enhancement of photocatalytic activity.

Figure 5. (A) Photocatalytic activities of the $\mathrm{Fe} / \mathrm{M}: \mathrm{TiO}_{2}$ against gaseous acetaldehyde under visible light irradiation of (a) $\lambda=470 \mathrm{~nm}$ and (b) $\lambda=625 \mathrm{~nm}$; (B) The amount of (a) $\bullet \mathrm{O}_{2}{ }^{-}$ and (b) $\mathrm{H}_{2} \mathrm{O}_{2}$ generated on the $\mathrm{M}: \mathrm{TiO}_{2}$ and the $\mathrm{Fe} / \mathrm{M}: \mathrm{TiO}_{2}$, respectively under visible light irradiation of $\lambda=625 \mathrm{~nm}$; (C) Schematic energy level diagram for the $\mathrm{Fe} / \mathrm{M}_{\mathrm{TiO}}$. Reprinted with permission from [25]. (C) 2014 Elsevier B. V.

A
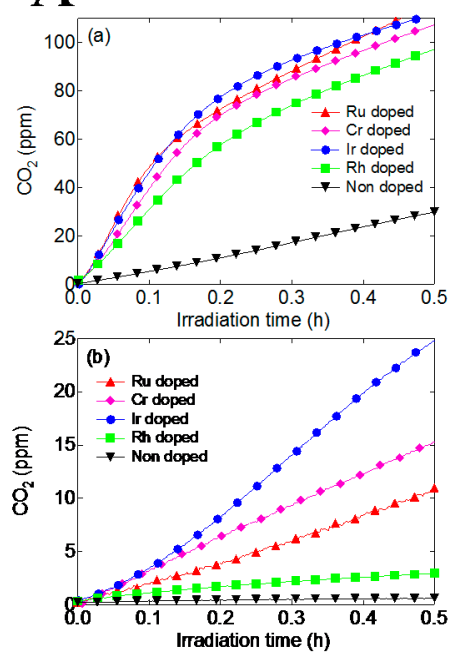
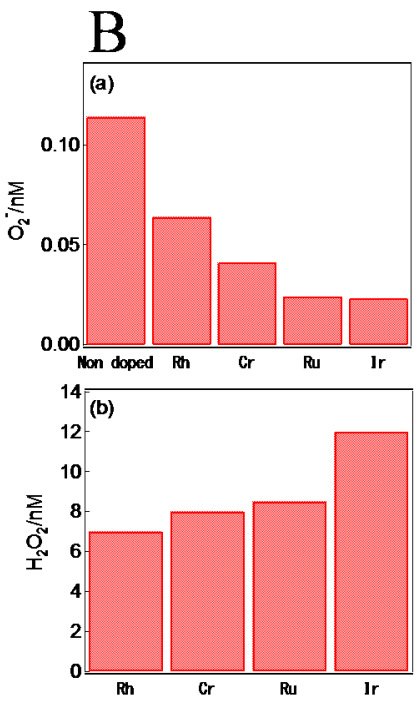

$\mathrm{C}$

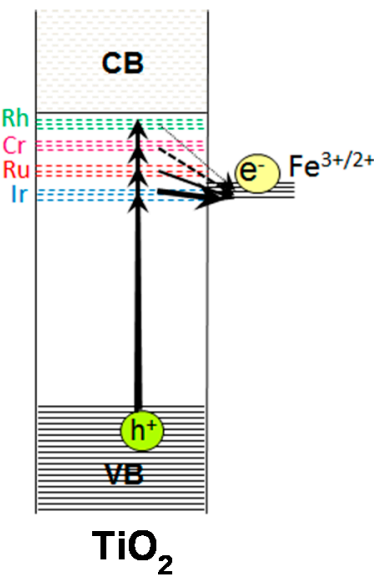

Furthermore, we examined the desirable character of doped metal ions for photocatalytic performance in detail. Figure 5B shows the amounts of $\bullet \mathrm{O}_{2}{ }^{-}$and $\mathrm{H}_{2} \mathrm{O}_{2}$ generated on the $\mathrm{M}: \mathrm{TiO}_{2}$ and the $\mathrm{Fe} / \mathrm{M}: \mathrm{TiO}_{2}$, respectively, under visible light irradiation. The electrons having a potential energy of $+0.38 \mathrm{~V}$ ( $v s$. SHE at $\mathrm{pH}=0)$ can reduce $\mathrm{O}_{2}$ into $\bullet \mathrm{O}_{2}{ }^{-}$under the experimental conditions $(\mathrm{pH}=11.5)$ [24]. Therefore, by measuring the amount of $\cdot \mathrm{O}_{2}^{-}$, the redox potential of dopants can be relatively estimated. For the 
non-doped $\mathrm{TiO}_{2}$, the generation amount of $\cdot \mathrm{O}_{2}{ }^{-}$was larger than that of the $\mathrm{M}: \mathrm{TiO}_{2}$. For the non-doped $\mathrm{TiO}_{2}, \mathrm{O}_{2}$ was reduced to $\cdot \mathrm{O}_{2}{ }^{-}$by an electron excited at conduction band from defect level under visible light irradiation. This result indicated that all kinds of dopant used played a role as acceptor, because if they play a role as donor, the generation amount of $\bullet \mathrm{O}_{2}{ }^{-}$should increase due to electron excitations from dopants to $\mathrm{CB}$. Among the $\mathrm{M}: \mathrm{TiO}_{2}$, the generation amount of $\bullet \mathrm{O}_{2}{ }^{-}$was decreased in the order of $\mathrm{Rh}>\mathrm{Cr}>\mathrm{Ru}>\mathrm{Ir}$. Since the order of the redox level of dopants should be consistent with that of the $\cdot \mathrm{O}_{2}{ }^{-}$amount, their redox levels would be more negative in the order of $\mathrm{Rh}>\mathrm{Cr}>\mathrm{Ru}>\mathrm{Ir}$. Secondly, when electrons transfer to the grafted $\mathrm{Fe}^{3+}$, the excited $\mathrm{Fe}^{2+}$ can reduce $\mathrm{O}_{2}$ to $\mathrm{H}_{2} \mathrm{O}_{2}$ by a two-electron process as mentioned below. Therefore, we can determine the degree of electron transfer to the $\mathrm{Fe}^{3+}$ from the dopants by the measurement of amount of $\mathrm{H}_{2} \mathrm{O}_{2}$. The generation amount of $\mathrm{H}_{2} \mathrm{O}_{2}$ was decreased in the order of $\mathrm{Ir}>\mathrm{Ru}>\mathrm{Cr}>\mathrm{Rh}$ (Figure 5B). This $\mathrm{H}_{2} \mathrm{O}_{2}$ generation tendency was opposite to that of $\cdot \mathrm{O}_{2}{ }^{-}$. This means that through the dopant with more positive redox potential, electrons can transfer more easily to the $\mathrm{Fe}^{3+}$ as illustrated in Figure 5C. This is due to the small energy loss of electrons when the redox potential of dopant was close to that of the $\mathrm{Fe}^{3+}$. Therefore, we concluded that the high photocatalytic activity of the $\mathrm{Fe} / \mathrm{Ir}: \mathrm{TiO}_{2}$ under visible light irradiation was attributable to the acceptor level due to $\mathrm{Ir}^{4+}$ formed close to the redox potential of the grafted $\mathrm{Fe}^{3+}$ (Figure 5C).

In the case of $\mathrm{TiO}_{2}$ codoped with $\mathrm{Rh}$ and $\mathrm{Sb}$ ions, the efficiency of the indirect electron transfer to the $\mathrm{Fe}^{3+}$ was lowered compared to the $\mathrm{TiO}_{2}$ doped with $\mathrm{Rh}$ ions alone (Figure 6A). By codoping with Sb ions, $\mathrm{Rh}^{4+}$ was reduced to $\mathrm{Rh}^{3+}$ and the formed $\mathrm{Rh}^{3+}$ played a role as donor [26,27]. This indicated that the efficiency of the indirect electron transfer of $\mathrm{Rh}^{3+} \rightarrow \mathrm{CB} \rightarrow \mathrm{Fe}^{3+}$ was lower than that of $\mathrm{VB} \rightarrow \mathrm{Rh}^{4+} \rightarrow \mathrm{Fe}^{3+}$ (Figure 6B).

Figure 6. (A) The co-doped effect on photocatalytic activities for $\mathrm{CO}_{2}$ formation from gaseous acetaldehyde under visible light irradiation of $\lambda=470 \mathrm{~nm}$. (a) Before and (b) after grafting of $\mathrm{Fe}^{3+}$; (B) Indirect electron transfer paths to the $\mathrm{Fe}^{3+}$ via (a) donor level and (b) acceptor level. Reprinted with permission from [25]. C) 2014 Elsevier B. V.
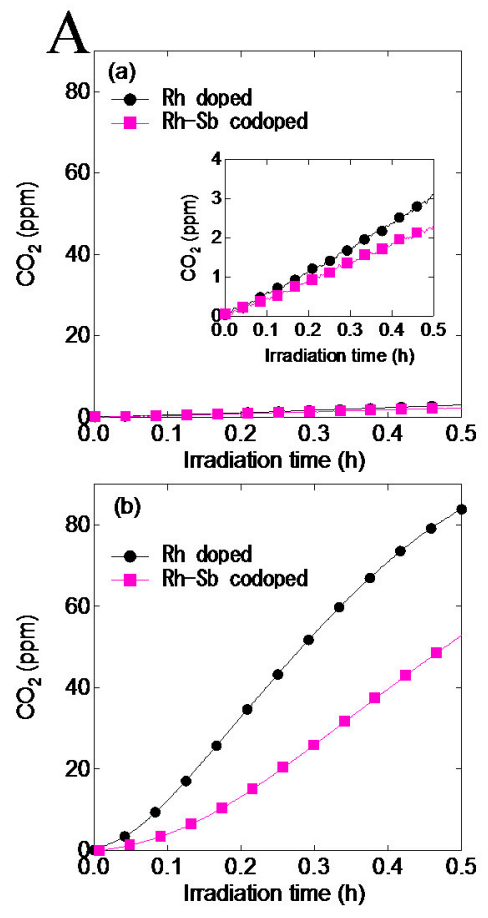

B

(a)

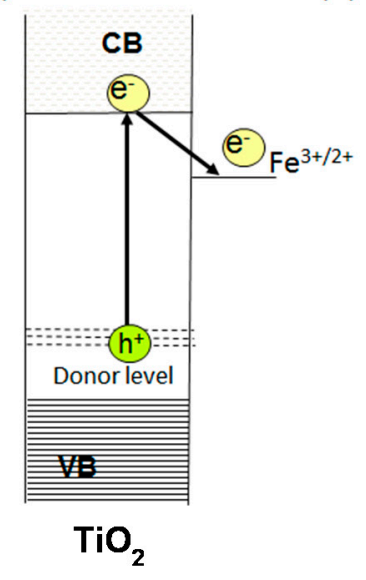

(b)

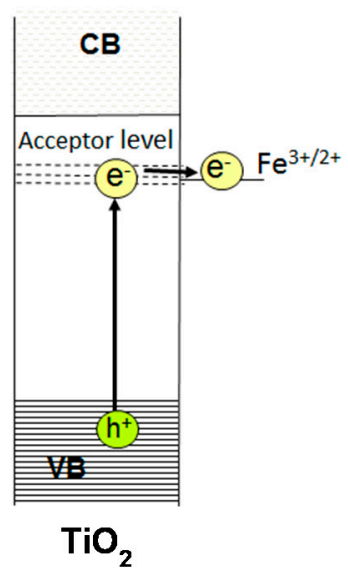


The energy gap of the redox potential between conduction band and the grafted $\mathrm{Fe}^{3+}$ was larger than that between the doped $\mathrm{Rh}^{4+}$ and the grafted $\mathrm{Fe}^{3+}$ and therefore electrons photoexcited at $\mathrm{CB}$ could not effectively transfer to the $\mathrm{Fe}^{3+}$ because of the large energy loss. From these results, forming acceptor level closed to the redox potential of the grafted $\mathrm{Fe}^{3+}$ was important for high performance of $\mathrm{Fe} / \mathrm{TiO}_{2}$ based photocatalysts under visible light irradiation [25]. Recently, a better energy level matching in $\mathrm{Fe} / \mathrm{M}: \mathrm{TiO}_{2}$ was achieved by employing $\mathrm{Fe}^{3+}$ as a doping metal ion [28].

\subsubsection{Pt Chloride Deposited $\mathrm{TiO}_{2}$ Photocatalysts}

$\mathrm{Pt}^{4+}$ chloride deposited $\mathrm{TiO}_{2}\left(\mathrm{PtCl} / \mathrm{TiO}_{2}\right)$ also showed a photocatalytic activity under visible light irradiation and its quantum efficiency was 9.8\% [20]. In the past, Kisch et al., reported a mechanistic hypothesis to explain $\mathrm{PtCl} / \mathrm{TiO}_{2}$ activity [21,29]. The proposed hypothesis was that the $\mathrm{PtCl}$ undergoes homolytic Pt-Cl cleavage by absorbing of light, generating a $\mathrm{Pt}^{3+}$ intermediate and a chlorine atom, the $\mathrm{Pt}^{3+}$ injects an electron to the conduction band of $\mathrm{TiO}_{2}$, and then the $\mathrm{Cl}$ radical oxidizes organic compounds. However, it is not clear whether the $\mathrm{Pt}-\mathrm{Cl}$ cleavage in the $\mathrm{PtCl} / \mathrm{TiO}_{2}$ system would occur. In addition, there is no sufficient evidence to support the injection of electron from $\mathrm{Pt}^{3+}$ to the conduction band of $\mathrm{TiO}_{2}$. Therefore, we clarified the charge transfer between the $\mathrm{PtCl}$ and $\mathrm{TiO}_{2}$ under visible-light irradiation using ESR spectroscopy [30].

For a bare $\mathrm{TiO}_{2}$ without deposition of $\mathrm{PtCl}$, under visible light irradiation, both ESR signals assigned to trapped electrons and holes were not observed (Figure $7 \mathrm{~A}(\mathrm{a})$ ). For the $\mathrm{PtCl} / \mathrm{TiO}$, a signal assigned to $\mathrm{Pt}^{3+}$ was observed. This means that $\mathrm{Pt}^{4+}$ chloride complexes were charge-separated into $\mathrm{Pt}^{3+}$ and $\mathrm{Cl}$ radicals. Then in the $\mathrm{TiO}_{2}$ host, trapped electrons $(\mathrm{g} \approx 1.98)$ were observed (Figure $7 \mathrm{~A}(\mathrm{~b})$ ). These results proved that $\mathrm{TiO}_{2}$ could receive electrons from excited $\mathrm{Pt}^{3+}$ as well as the hypothetical mechanism. However, unlike the hypothetical mechanism, trapped hole signal $(\mathrm{g}=2.01)$ was also observed. Based on the results, some electrons in the $\mathrm{VB}$ of $\mathrm{TiO}_{2}$ would be excited to the orbital of the $\mathrm{Cl}$ radicals similarly to the case of direct electron transfer from the $\mathrm{VB}$ of $\mathrm{TiO}_{2}$ to the grafted $\mathrm{Fe}^{3+}$ for the $\mathrm{Fe} / \mathrm{TiO}_{2}$ photocatalysts. Since the redox potential $(+3.0 \mathrm{~V} v s . \mathrm{SHE}$ at $\mathrm{pH}=0)$ of the VB of rutile $\mathrm{TiO}_{2}$ is more positive than that $(2.47 \mathrm{~V}$ vs. $\mathrm{SHE}$ at $\mathrm{pH}=0)$ of $\mathrm{Cl} / \mathrm{Cl}^{-}$[31], the high photocatalytic activity of $\mathrm{PtCl} / \mathrm{TiO}_{2}$ would be owing to the generation of holes in the $\mathrm{TiO}_{2}$ host.

Generation behaviors of $\cdot \mathrm{O}_{2}{ }^{-}$and $\mathrm{H}_{2} \mathrm{O}_{2}$ under visible light irradiation were also examined for the $\mathrm{PtCl} / \mathrm{TiO}_{2}$ as shown in Figure $6 \mathrm{~B} \cdot \cdot \mathrm{O}_{2}{ }^{-}$was predominantly generated compared to $\mathrm{H}_{2} \mathrm{O}_{2}$. This was opposite behavior to the $\mathrm{Fe} / \mathrm{TiO}_{2}$ for which $\mathrm{H}_{2} \mathrm{O}_{2}$ was dominantly generated rather than $\bullet \mathrm{O}_{2}{ }^{-}$. This means that photoexcited electrons have a higher potential energy than $+0.38 \mathrm{~V}(v s . \mathrm{SHE}$ at $\mathrm{pH}=0)$ and therefore the reduction of $\mathrm{O}_{2}$ to $\cdot \mathrm{O}_{2}{ }^{-}$was produced by the electrons photoexcited at $\mathrm{CB}$ of $\mathrm{TiO}_{2}$, which supported the ESR results [30].

A plausible reaction mechanism for the $\mathrm{PtCl} / \mathrm{TiO}_{2}$ photocatalyst is illustrated in Figure $7 \mathrm{C}$. Photoexcited $\mathrm{Pt}^{3+}$ generated by ligand- metal charge transfer in deposited $\mathrm{PtCl}$ complex by adsorption of visible light gives an electron to the $\mathrm{TiO}_{2} \mathrm{CB}$ and then the electron is consumed by reduction of $\mathrm{O}_{2}$ into $\cdot \mathrm{O}_{2}{ }^{-}$. Some of the photogenerated $\mathrm{Cl}$ radicals can decompose organic substances and the other receive electrons by photo-excitation from the valence band of $\mathrm{TiO}_{2}$, resulting the generation of holes in $\mathrm{TiO}_{2}$. The organic substances can be efficiently decomposed by the generated holes in $\mathrm{TiO}_{2}$ with strong oxidation ability. 
Figure 7. (A) ESR spectra of electrons and holes for (a) $\mathrm{TiO}_{2}$ and (b) $\mathrm{PtCl} / \mathrm{TiO}_{2} ;$ (B) $(\mathbf{a}) \cdot \mathrm{O}_{2}{ }^{-}$ and (b) $\mathrm{H}_{2} \mathrm{O}_{2}$ generated on the $\mathrm{PtCl} / \mathrm{TiO}_{2}$ under visible light irradiation. (C) Photocatalytic reaction mechanism of $\mathrm{PtCl} / \mathrm{TiO}_{2}$. Reprinted with permission from [30]. (C) 2012 American Chemical Society.
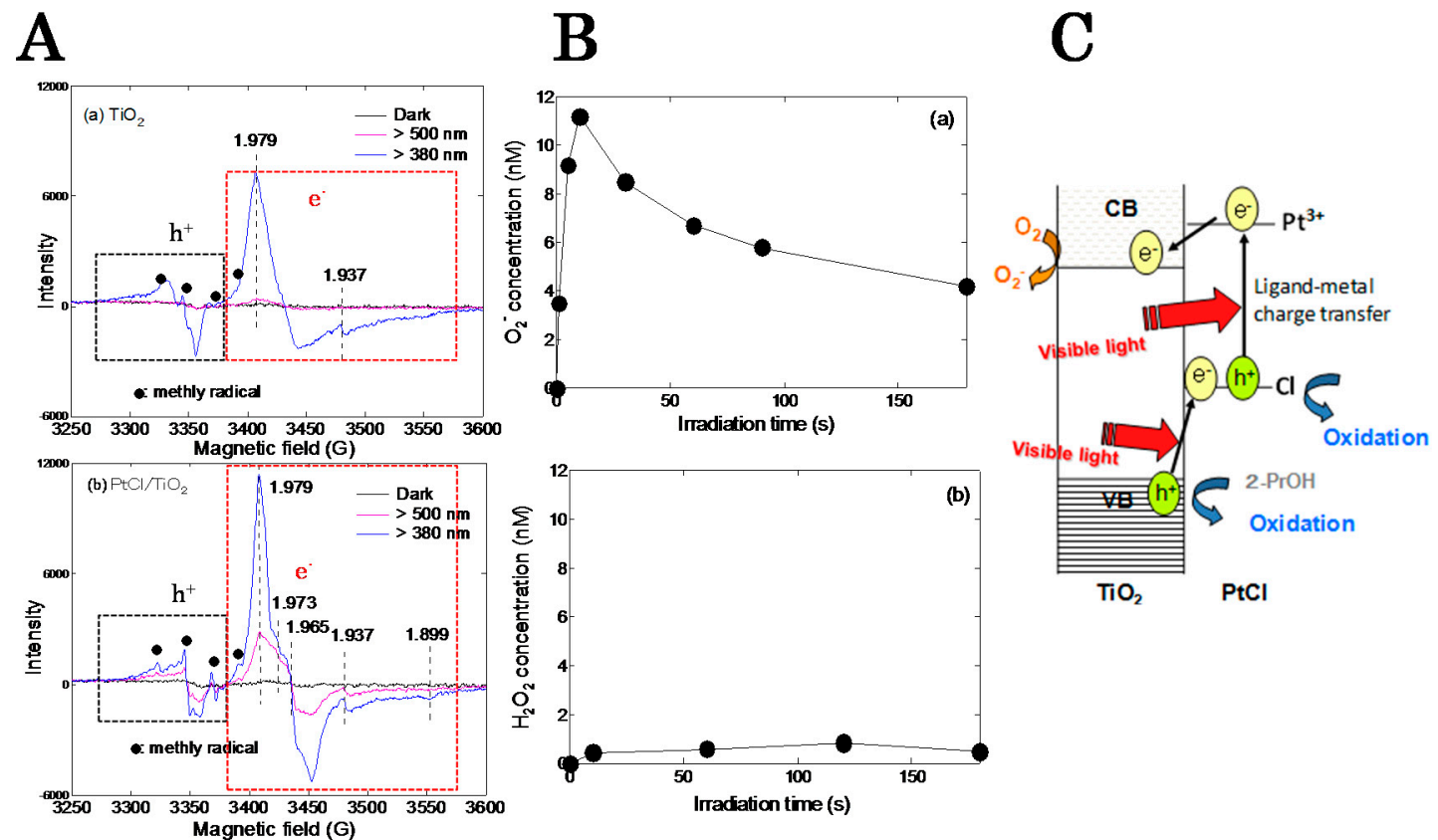

\subsubsection{Comparison of the Visible-Light Responsive $\mathrm{TiO}_{2}$ Photocatalysts}

The reaction mechanisms of various modified $\mathrm{TiO}_{2}$ were investigated by detecting $\bullet \mathrm{OH}$ quantitatively by means of a coumarin fluorescence probe method [18]. The photocatalysts investigated were nitrogen-doped, $\mathrm{Fe}$ (III)-grafted, $\mathrm{Fe}(\mathrm{III})$-grafted Ru-dopedTiO2, and Pt-complex-deposited, whose diffuse reflectance spectra are shown in Figure 8A. On the irradiation with $470 \mathrm{~nm}$ light in the presence of coumarin, the concentration of umbelliferone was increased (Figure 8B). From the slope, the formation rate of $\bullet \mathrm{OH}$ was calculated. Then, the $\bullet \mathrm{OH}$ quantum yield was calculated with the absorbed light intensity which was evaluated from the absorption and irradiance spectra in Figure 8A. The quantum yield ranged from $10^{-5}$ for $\mathrm{N}-\mathrm{TiO}_{2}$ to $4 \times 10^{-4}$ for $\mathrm{Fe} / \mathrm{TiO}_{2}$ [18]. In the presence of 0.14 $\mathrm{mM} \mathrm{H} \mathrm{H}_{2} \mathrm{O}_{2}$, the $\cdot \mathrm{OH}$ yield decreased for $\mathrm{N}-\mathrm{TiO}_{2}$ while it increased for $\mathrm{Fe} / \mathrm{TiO}_{2}$. The increase for $\mathrm{Fe} / \mathrm{TiO}_{2}$ suggests that $\mathrm{H}_{2} \mathrm{O}_{2}$ is a reaction intermediate for producing $\bullet \mathrm{OH}$.

The photocatalytic activity was evaluated by the rate of $\mathrm{CO}_{2}$ generation associated with acetaldehyde decomposition and then it was plotted in Figure 9A as a function of the $\cdot \mathrm{OH}$ formation rate for each photocatalyst. The $\mathrm{CO}_{2}$ generation rates of the photocatalysts were positively correlated with those of the $\cdot \mathrm{OH}$ formation. However, the formation rates of $\mathrm{CO}_{2}$ were extremely larger $\left(10^{3}\right.$ times) than those of $\bullet \mathrm{OH}$. This finding indicates that the oxidation reaction predominantly takes place at the photocatalyst surface with the trapped holes. The good correlation in the figure suggests that $\cdot \mathrm{OH}$ in the bulk solution is equilibrated with trapped holes (Equation (1)), but the equilibrium is significantly shifted to the surface trapped holes.

$$
\cdot \mathrm{OH}+\mathrm{Ti}^{4+}\left[\mathrm{TiO}_{2}\right] \longleftarrow \longrightarrow \cdot \mathrm{O}^{-} \mathrm{Ti}^{4+}\left[\mathrm{TiO}_{2}\right]+\mathrm{H}^{+}
$$


Figure 8. (A) Absorption spectra as the complement of the reflectance (1-R) and the irradiance spectra of LED used in the study; (B) Concentration of umbelliferone generated under 470-nm irradiation in aqueous coumarin solution was plotted as a function of the irradiation time. Reprinted with permission from [18]. (C) 2013 American Chemical Society.

A

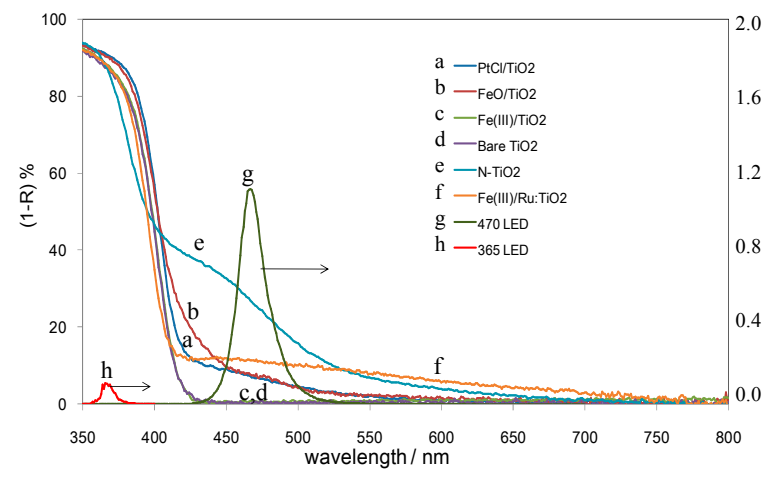

B

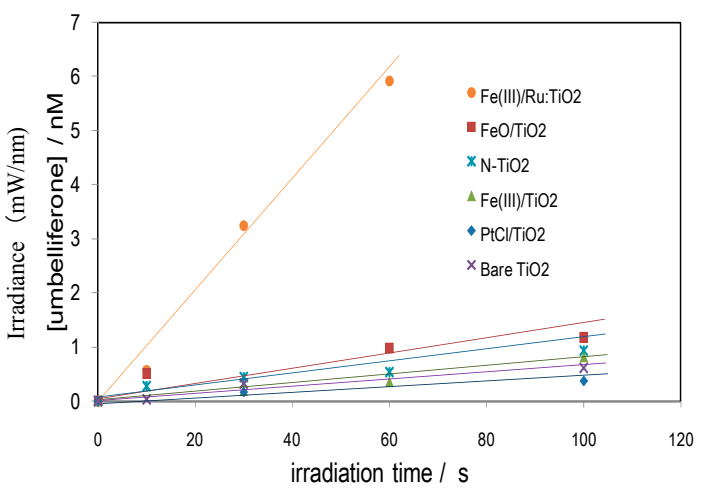

The highest photocatalytic activity in the suspension system was obtained for Fe(III)-deposited Ru-doped $\mathrm{TiO}_{2}\left(\mathrm{Fe}(\mathrm{III}) / \mathrm{Ru}: \mathrm{TiO}_{2}\right)$ whose reaction mechanism is shown in Figure 9B. On the basis of the ESR and chemiluminescence experiments mentioned above [23], the CB electrons are formed by two step excitation with visible light irradiation and $\mathrm{O}_{2}$ is reduced to $\mathrm{H}_{2} \mathrm{O}_{2}$. The grafted $\mathrm{Fe}^{3+}$ is reduced by $\mathrm{Ru}^{3+}$ or by IFCT and then the formed $\mathrm{Fe}^{2+}$ produces $\bullet \mathrm{OH}$ from $\mathrm{H}_{2} \mathrm{O}_{2}$. The $\bullet \mathrm{OH}$ produced in solution is adsorbed on the $\mathrm{TiO}_{2}$ surface to form trapped holes which could oxidize organic compounds, such as acetaldehyde, leading to $\mathrm{CO}_{2}$.

Figure 9. (A) Relationship between the formation rates of $\mathrm{CO}_{2}$ and $\cdot \mathrm{OH}$ under the irradiation of $470 \mathrm{~nm}$ LED. The $\mathrm{CO}_{2}$ formation rate is a measure of the photocatalytic reaction rate in the acetaldehyde decomposition in aqueous suspension system; (B) Schematic illustration of reaction mechanism of $\mathrm{Fe}(\mathrm{III})$-grafted $\mathrm{Ru}$-doped $\mathrm{TiO}_{2}$ photocatalyst based on the detection of $\bullet \mathrm{OH}$ and $\mathrm{CO}_{2}$. Key: IFCT, interfacial charge transfer; $\mathrm{h}^{+}$tr, surface trapped hole. Reprinted with permission from [18]. (C) 2013 American Chemical Society.

A

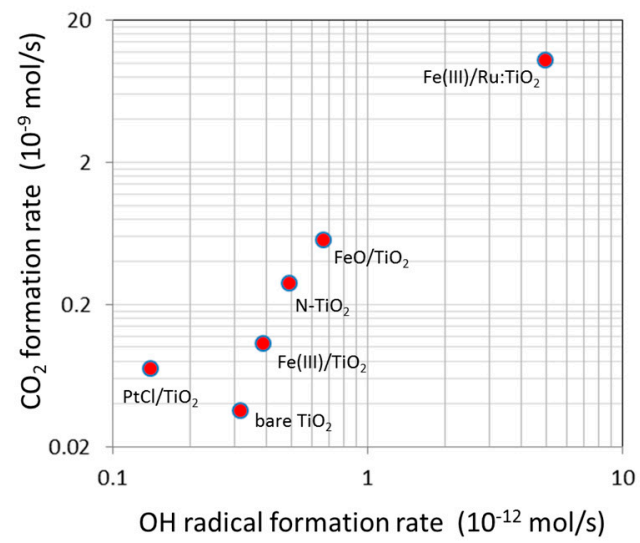

B

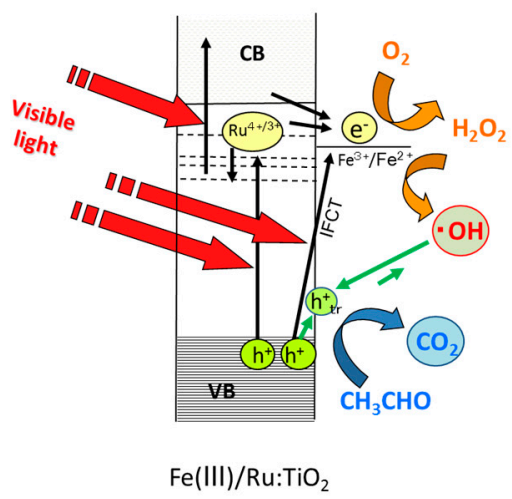




\subsection{Photocatalysis with Bare $\mathrm{TiO}_{2}$}

\subsubsection{Reactivities of Rutile and Anatase Surfaces}

The photogeneration of molecular oxygen at rutile $\mathrm{TiO}_{2}$ electrode is a famous historical reaction [32]. To investigate the oxidation mechanism, $\bullet \mathrm{OH}$ formation was measured by employing three electrodes of rutile $\mathrm{TiO}_{2}$ (100), (110), and (001) [33]. Figure 10A shows the amount of the produced umbelliferone, which is normalized to the number of charges used in the reaction. For all electrodes, the photocurrent efficiency of $\cdot \mathrm{OH}$ was less than $1 \%$, while that of $\mathrm{O}_{2}$ was about $100 \%$. This observation implies that the conventionally proposed mechanism to produce $\mathrm{O}_{2}$ via $\bullet \mathrm{OH}$ formation is not a major mechanism in water oxidation at $\mathrm{TiO}_{2}$ surface. Figure $10 \mathrm{~B}$ shows the plausible reaction steps in the formation of $\mathrm{O}_{2}$ and $\cdot \mathrm{OH}$ through surface peroxo (Ti-O-O-Ti). By cleaving Ti-O bond in the peroxo, $\mathrm{O}_{2}$ is formed as shown in Figure $10 \mathrm{~B}(\mathrm{a})$ [34]. When O-O bond is cleaved instead of Ti-O bond, $\bullet \mathrm{OH}$ is formed as a byproduct. The $\cdot \mathrm{OH}$ formation in Figure $10 \mathrm{~A}$ increases in the order of $(001)<(110)<(100)$, which can be explained by the strength of Ti-O bond deduced from the surface structure [33].

Figure 10. (A) The amount of produced umbelliferone normalized for the current charge is plotted against the coumarin concentration in solution for the rutile (100), (110), and (001) $\mathrm{TiO}_{2}$ electrodes; (B) Plausible reaction steps starting from peroxo to form (a) $\mathrm{O}_{2}$ and (b) $\cdot \mathrm{OH}$ at the $\mathrm{TiO}_{2}$ surface. Reprinted with permission from [33]. (C) 2013 American Chemical Society.

A

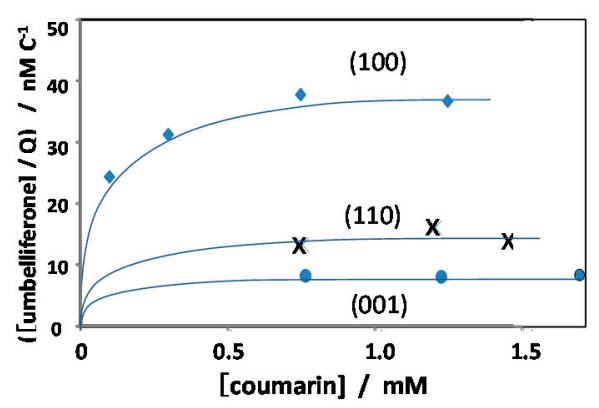

B

(a)
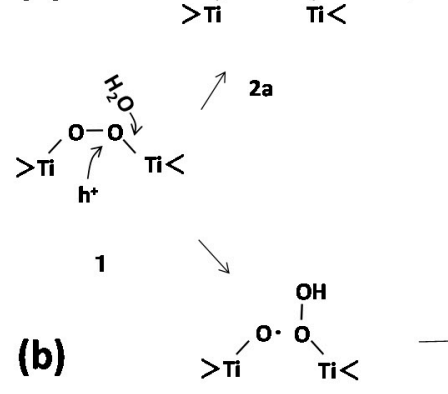

$\mathbf{2 b}$

(b) 3a

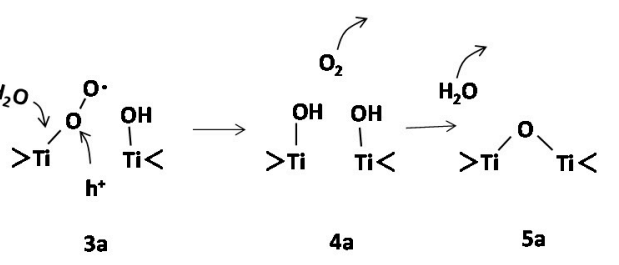

$5 a$

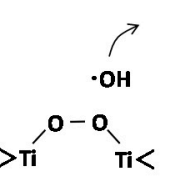

3b

Though rutile $\mathrm{TiO}_{2}$ shows high activity for $\mathrm{O}_{2}$ evolution, anatase $\mathrm{TiO}_{2}$ is known to have a higher activity in the photocatalytic oxidation of organic molecules [35]. The difference in the generation process of $\bullet \mathrm{OH}$ between rutile and anatase was investigated by using CCA and coumarin [36]. Figure $11 \mathrm{~A}$ shows the quantum yields of $\bullet \mathrm{OH}$ generation measured with coumarin and CCA together with the adsorbed fraction of CCA. As shown in Figure 11A, anatase and anatase-contained $\mathrm{TiO}_{2}$ (ST-01, P25, and F1) generated $\bullet \mathrm{OH}$ in the substantial yields. The quantum yield for $\mathrm{OH}-\mathrm{CCA}$ was much larger than that for umbelliferone, indicating that $\bullet \mathrm{OH}$ is formed at the $\mathrm{TiO}_{2}$ surface and diffused into bulk solution. Furthermore, this observation indicates that the active site is different from the adsorption site of $-\mathrm{COO}^{-}$group. Since $\mathrm{H}_{2} \mathrm{O}_{2}$ is produced in photocatalysis, the effect of $\mathrm{H}_{2} \mathrm{O}_{2}$ on the 
- $\mathrm{OH}$ generation was investigated. Figure $11 \mathrm{~B}$ shows the effect of the addition of $\mathrm{H}_{2} \mathrm{O}_{2}$ on the formation rate for (a) $\mathrm{OH}-\mathrm{CCA}$ and (b) umbelliferone. On the addition of $\mathrm{H}_{2} \mathrm{O}_{2}$, the $\bullet \mathrm{OH}$ generation for pure anatase $\mathrm{TiO}_{2}$ decreased but increased for rutile and rutile-contained $\mathrm{TiO}_{2}$. This phenomenon has been reported previously for other several $\mathrm{TiO}_{2}$ powders [37]. The amount of $\bullet \mathrm{O}_{2}{ }^{-}$was significantly increased with the addition of $\mathrm{H}_{2} \mathrm{O}_{2}$ [37]. Although the formation of $\bullet \mathrm{OH}$ from $\mathrm{H}_{2} \mathrm{O}_{2}$ by $\mathrm{CB}$ electrons is commonly suggested in the $\bullet \mathrm{OH}$ generation mechanism, the fact that the $\bullet \mathrm{O}_{2}{ }^{-}$was significantly increased with $\mathrm{H}_{2} \mathrm{O}_{2}$ denied the one-electron reduction of $\mathrm{H}_{2} \mathrm{O}_{2}$.

Figure 11. (A) Quantum yields of $\bullet \mathrm{OH}$ using the different probe molecules, coumarin (blue) and CCA (brown), and the fraction of adsorbed CCA (green) for four kinds of $\mathrm{TiO}_{2}$ powders; (B) Effect of the addition of $0.14 \mathrm{mM} \mathrm{H}_{2} \mathrm{O}_{2}$ on the formation rates of (a) OH-CCA and (b) umbelliferone. Reprinted with permission from [36]. (C) 2014 American Chemical Society.
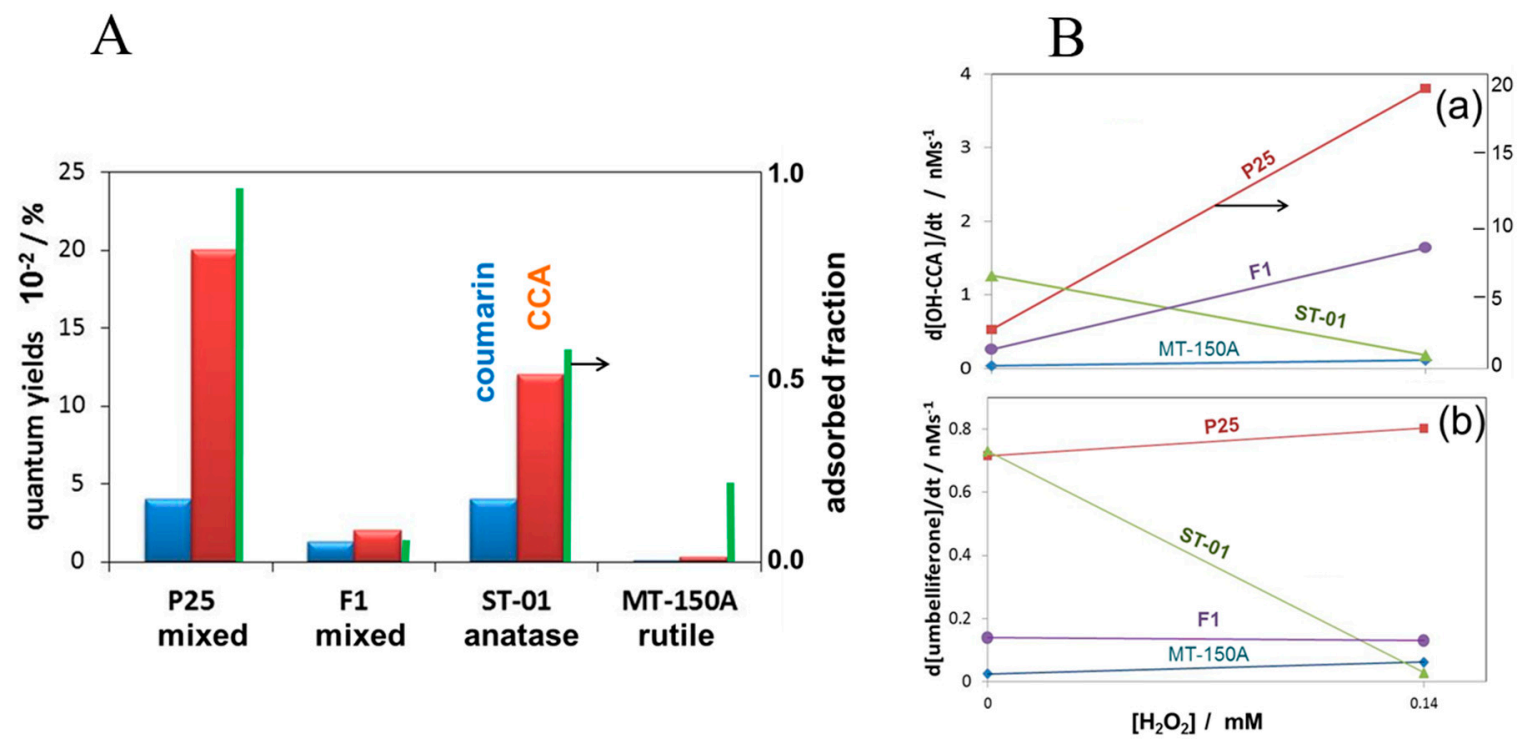

Since the increase is remarkable for anatase than rutile $\mathrm{TiO}_{2}$, with the addition of $\mathrm{H}_{2} \mathrm{O}_{2}$, the generation of $\bullet \mathrm{OH}$ at anatase surface was replaced by the oxidation of $\mathrm{H}_{2} \mathrm{O}_{2}$ to form $\bullet \mathrm{O}_{2}{ }^{-}$, as illustrated in Figure 12A.

For rutile $\mathrm{TiO}_{2}$ adsorbed $\mathrm{H}_{2} \mathrm{O}_{2}$ is equivalent to the surface peroxo, Ti-O-O-Ti and promotes the formation of $\bullet \mathrm{OH}$ as stated above. The detailed generation mechanism of $\bullet \mathrm{OH}$ on anatase and rutile $\mathrm{TiO}_{2}$ surfaces can be proposed as shown in Figure 12B. On the anatase surface, photogenerated valence band holes, $\mathrm{h}^{+}$, are trapped at the surface oxygen to form trapped holes $\left(\mathrm{Ti}-\mathrm{O}^{\bullet}\right)$ that can be regarded as the adsorbed $\bullet \mathrm{OH}$ in the deprotonated form $\left(\bullet \mathrm{O}^{-}\right)$[18] then an $\bullet \mathrm{OH}$ is released to the solution as represented by Equation (1). On the other hand, for rutile $\mathrm{TiO}_{2}$, since the crystalline structure is packed more tightly than that for anatase, the stability of the surface trapped holes may be different. By trapping of $\mathrm{h}^{+}$predominantly near the trapped hole, Ti-peroxo is formed. As described above in Figure $10 \mathrm{~B}(\mathrm{~b}), \cdot \mathrm{OH}$ radical is produced by $\mathrm{h}^{+}$from $\mathrm{H}_{2} \mathrm{O}$ with Ti-peroxo, which plays the role of a catalyst. Thus, the increase of the $\cdot \mathrm{OH}$ generation with $\mathrm{H}_{2} \mathrm{O}_{2}$ for rutile $\mathrm{TiO}_{2}$ can be explained. 
Figure 12. (A) Photocatalytic processes at the conduction band (C.B.) and the valence band (V.B.) of $\mathrm{TiO}_{2}$ with anatase and rutile crystalline types in the absence and the presence of $\mathrm{H}_{2} \mathrm{O}_{2}$. The thickness of arrows expresses the degree of the reaction rate; (B) Plausible mechanisms of $\bullet \mathrm{OH}$ generation at anatase $\mathrm{TiO}_{2}$ (upper part) and rutile $\mathrm{TiO}_{2}$ (lower part). Reprinted with permission from [36]. C) 2014 American Chemical Society.

A

Anatase $\mathrm{TiO}_{2}$

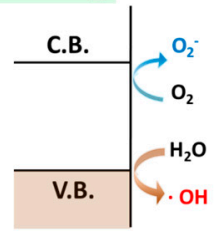

Rutile $\mathrm{TiO}_{2}$

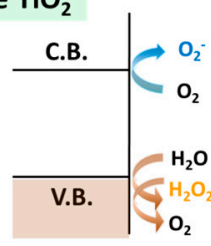

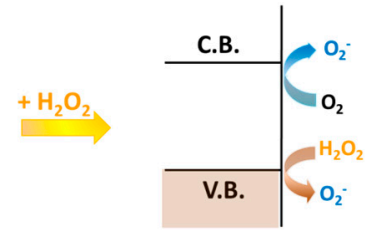
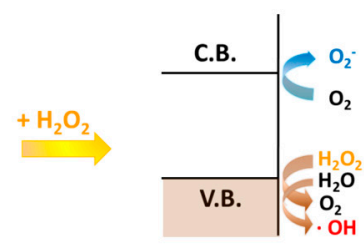

B

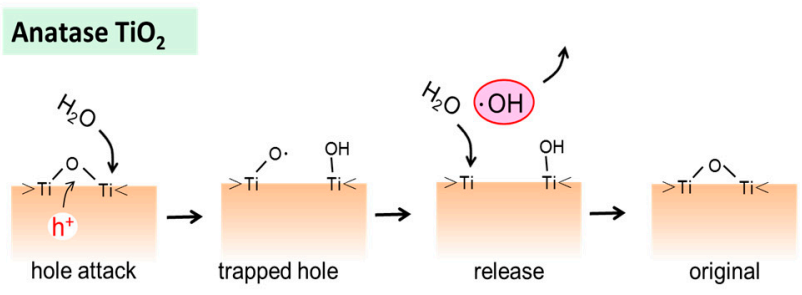

Rutile $\mathrm{TiO}_{2}$

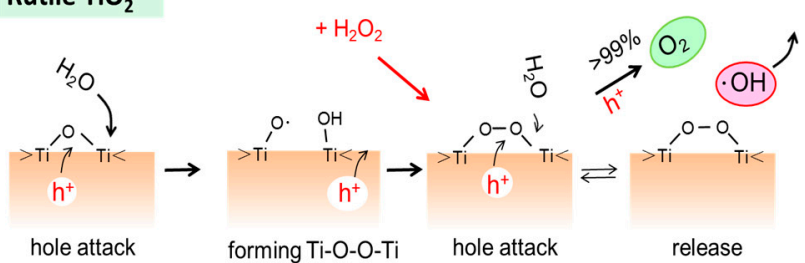

\subsubsection{Adsorption and Decomposition of Glycine Related Peptides}

The application of photocatalysts to biological fields for their antibacterial effect and in medical treatments for diseases, including cancer, has been proceeding extensively [38,39]. It is believed that the active oxygen species generated on the photocatalysts such as $\mathrm{H}_{2} \mathrm{O}_{2}, \bullet \mathrm{OH}$, and singlet oxygen are involved in the attack to kill various kinds of virus and bacteria [40]. However, the mechanism underlying the photobiological activity is not yet well understood. Since the photocatalytic process is expected to occur at the interface between the photocatalysts and the liquid medium, the interface between protein molecules and inorganic materials has recently received much attention.

Proteins and peptides are composed of various kinds of amino acids. For a proper understanding of the adsorptive and photocatalytic interactions between the surface of the photocatalysts and proteins/peptides, fundamental knowledge on the adsorption and photocatalytic reactivity of individual constituent amino acids would be necessary.

$\mathrm{TiO}_{2}$ is widely used for practical applications as a photocatalyst. The surface of $\mathrm{TiO}_{2}$ is amphiphilic, which consists of hydrophobic and hydrophilic parts [41]. The hydrophilic parts involve two kinds of hydroxyl group, that is, the acidic bridged hydroxyl group and the basic terminal hydroxyl group. Both groups can be adsorptive and/or photocatalytic active sites, depending on the kinds of titanium dioxides which are characterized by different particle size, surface area, and crystal forms such as anatase, rutile and brookite. The photocatalyst with different characteristic surface shows different adsorbability and photocatalytic activity [40].

It was demonstrated that both hydrophilic and hydrophobic sites are adsorptive sites but that only hydrophobic sites are photocatalytically active for ST-01 $\mathrm{TiO}_{2}(100 \%$ anatase crystal form with a BET surface area of $320 \mathrm{~m}^{2} \cdot \mathrm{g}^{-1}$ and a particle size of $9 \mathrm{~nm}$; Ishihara Sangyo Ltd., Osaka, Japan) [15]. 
After the calcinations at $973 \mathrm{~K}$ hydrophilic parts of the surface of ST-01 can be eliminated and a highly hydrophobic surface (designated as $\mathrm{HT}^{-} \mathrm{TiO}_{2}$ ) is created without changing the crystal form [15]. By employing these characteristics, the adsorption and decomposition sites of the simplest amino acid glycine, whose adsorbability on the $\mathrm{TiO}_{2}$ surface is still controversial [42], and its homopeptides (Gly-Gly and Gly-Gly-Gly) were investigated by ${ }^{1} \mathrm{H}-\mathrm{NMR}$ spectroscopy [43]. For Gly-Gly and Gly-Gly-Gly the carboxylic group and the peptide bond were assigned as the adsorptive sites of the peptides on the surface of ST-01. The adsorption feature of Gly-Gly-Gly on $\mathrm{TiO}_{2}$ (ST-01) are illustrated in Figure 13; the peptide would adsorb by the $C$-terminal carboxyl group most probably with the terminal hydroxyl group at 5-coordinated $\mathrm{Ti}$ of $\mathrm{TiO}_{2}$ as is generally believed [42]. The photo decomposition took place by the weak adsorption of the peptide bonds on the surface of $\mathrm{TiO}_{2}(\mathrm{ST}-01)$.

Figure 13. Schematic presentation of the adsorption of the peptide (Gly-Gly-Gly) on the hydrophilic and hydrophobic surface of $\mathrm{TiO}_{2}$ (ST-01). Reprinted with permission from [43] (C) 2014 American Chemical Society.

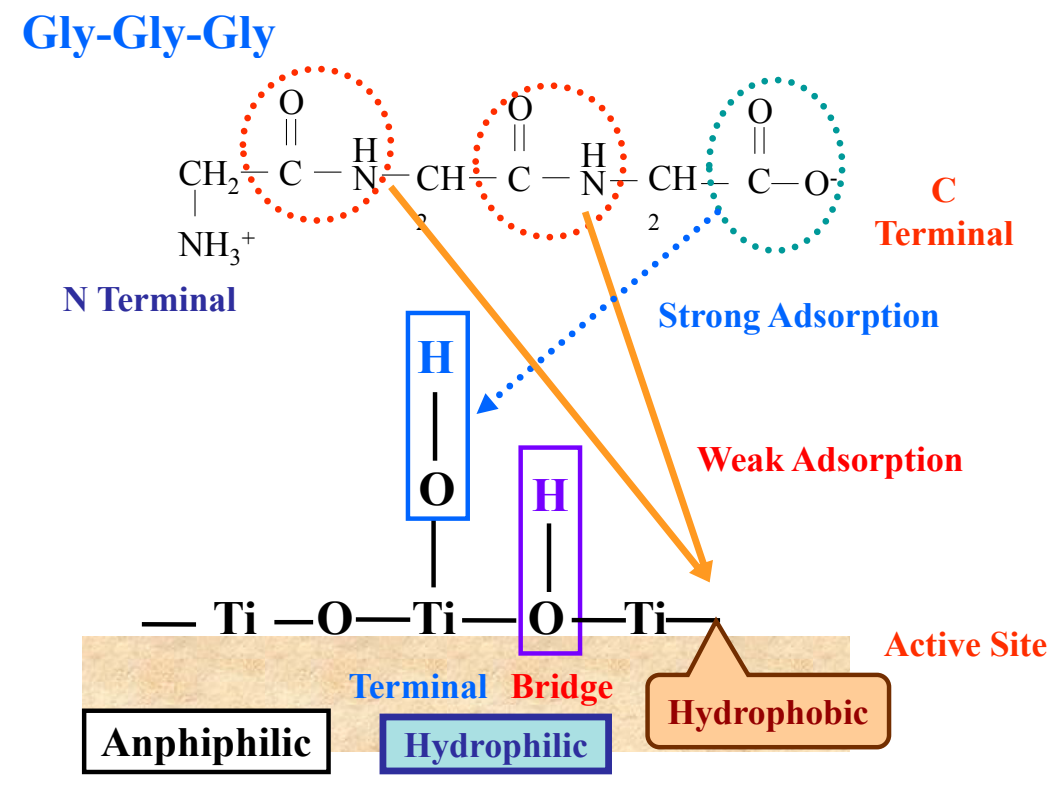

On the other hand, when a hydrophobic side chain Leu is incorporated, in addition to the peptide bonds and the carboxylic group, the adsorption of hydrophobic leucyl residue on the hydrophobic parts of $\mathrm{TiO}_{2}$ surface would take place. As shown in Figure 14, for $\mathrm{HT}_{-} \mathrm{TiO}_{2}$, the adsorption of the Leu- containing peptides increased with the increase of the number of the peptide bond that is, Leu $<$ Leu-Gly, Gly-Leu < Leu-Gly-Gly (Figure 14C).

However, the decomposition rates are almost the same (Figure 14D). These facts suggest that both the peptide bond and leucyl side chain could adsorb on the hydrophobic surface of $\mathrm{TiO}_{2}$ but photocatalytic decomposition should take place through the adsorption of the leucyl side chain which would adsorb preferably on the photocatalytic active part of the hydrophobic $\mathrm{TiO}_{2}$ surface. Thus leucyl residue would adsorb preferably on the active site of the hydrophobic part of $\mathrm{TiO}_{2}$ instead of the peptide bonds and photocatalysis proceeds. The adsorption feature of Leu-Gly-Gly, on $\mathrm{TiO}_{2}(\mathrm{ST}-01)$ are illustrated in Figure 15. 
Figure 14. Equilibrium adsorption and rate of decomposition under the UV irradiation measured at $297 \mathrm{~K}$ for Leu, Leu-Gly, Gly-Leu, and Leu-Gly-Gly in the aqueous suspensions of $\mathrm{TiO}_{2} ;(\mathbf{A}, \mathbf{B})$ for untreated $\mathrm{TiO}_{2}$ and $(\mathbf{C}, \mathbf{D})$ for $\mathrm{HT}-\mathrm{TiO}_{2}\left(\mathrm{TiO}_{2}\right.$ calcined at 973 K). Reprinted with permission from [43] (C) 2014 American Chemical Society.
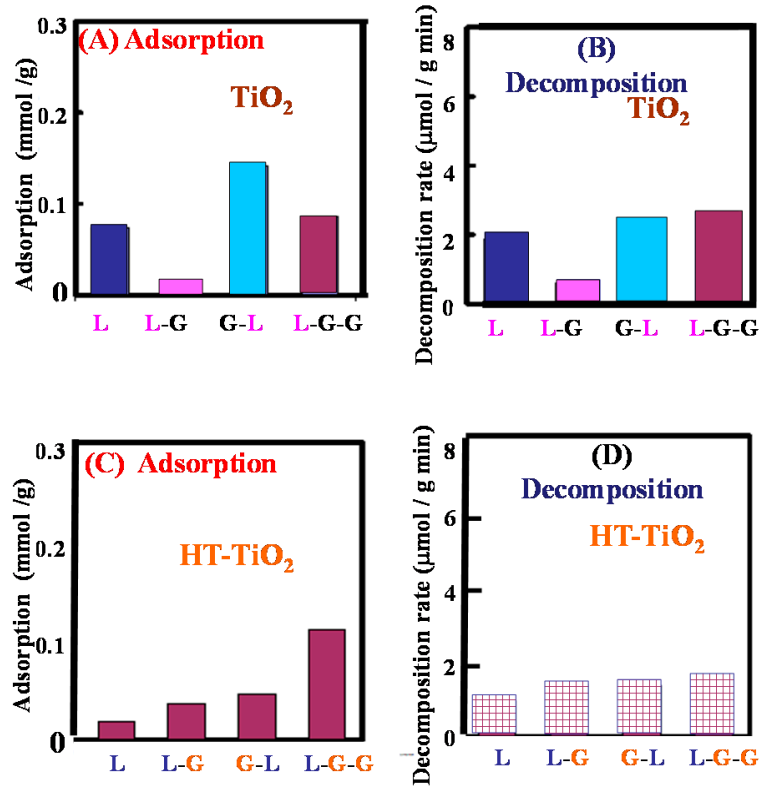

Figure 15. Schematic presentation of the plausible adsorption of the peptide (Leu-Gly-Gly) on the hydrophilic and hydrophobic surface of $\mathrm{TiO}_{2}$ (ST-01). Reprinted with permission from [43] C) 2014 American Chemical Society.

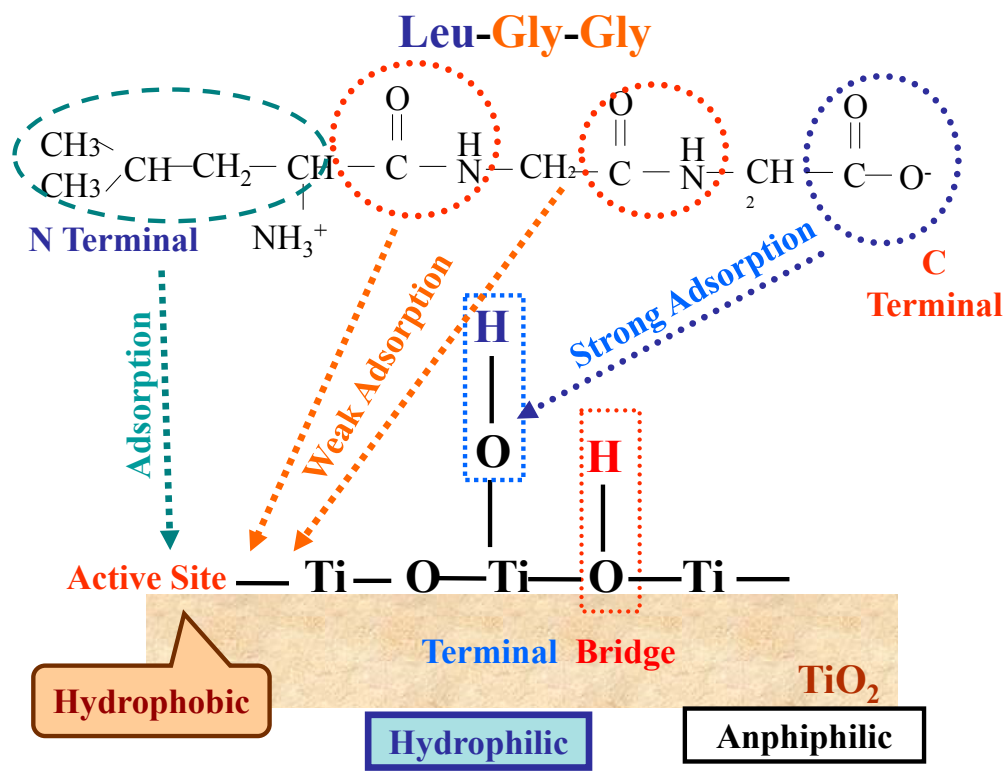

However, as shown in Figure 14A,B it was found that Leu-Gly showed remarkably low adsorbability and decomposition rate as compared to Gly-Leu due to the specific conformation, in which the positively charged amino group and negatively charged carboxyl group interact strongly by electrostatic force [43]. Thus, when a peptide or proteins take a specific conformation, photocatalysis does not work effectively. For the effective use of $\mathrm{TiO}_{2}$ it would be necessary to acquire information 
on the surface conformation of the corresponding proteins/peptides to access the surface of the photocatalysts. By combining the information about the surface conformation of proteins/peptides and the active sites of $\mathrm{TiO}_{2}$ (hydrophobic or hydrophilic), we could design the $\mathrm{TiO}_{2}$ effective to diminish the specific virus, bacteria or environmental hazardous materials.

\subsubsection{Glutathione and Related Amino Acids}

With increased applications of $\mathrm{TiO}_{2}$ nanoparticles, the concerns about their potential human toxicity and their environmental impact have also increased. Although details of human biological responses to $\mathrm{TiO}_{2}$ exposure are still unavailable, numerous in vitro examinations concerning cellular responses induced by $\mathrm{TiO}_{2}$ have been reported [44-46].

Glutathione is a tri-peptide capable of diminishing active oxygen species in living cells. In spite of the importance of glutathione in defense against oxidative stress, its actual affects and the mechanism for the $\mathrm{TiO}_{2}$-induced cytotoxicity and genotoxicity have not been completely elucidated yet.

The photocatalytic decomposition of glutathione and related amino acids in $\mathrm{TiO}_{2}$ suspension was investigated with ${ }^{1} \mathrm{H}$ NMR spectroscopy [47]. The results suggest, that as shown in Figure 16A, both glutathione in reduced (GSH) and oxidative forms (GSSG) are adsorbed on the $\mathrm{TiO}_{2}$ surface by carboxyl or amino groups but not by the thiol group $(\mathrm{SH})$ of the side chain which plays a crucial role in the glutathione cycle (Scheme 1), to be degraded. This suggests that the function of glutathione cycle should be deteriorated in living cells by the adsorption. However, the decomposition rates are considerably slow as compared with those of the constituent amino acids (Glu, Cys and Gly) as shown in Figure 16B, possibly reflecting the self-defensive property against active oxygen species.

Figure 16. (A) Schematic presentation of the plausible adsorption of glutathione on the surface of $\mathrm{TiO}_{2}$ (ST-01); (B) (a) Adsorption and (b) decomposition rates of glutathione (GSH and GSSG) and the constituent amino acids (Glu, Cys, and Gly) in aqueous suspension of $\mathrm{TiO}_{2}(5 \mathrm{mg} / 0.4 \mathrm{~mL} \mathrm{D} 2 \mathrm{O})$ under UV irradiation at $297 \mathrm{~K}$. Reprinted with permission from [47] (C) 2012 American Chemical Society.

A

glutathione

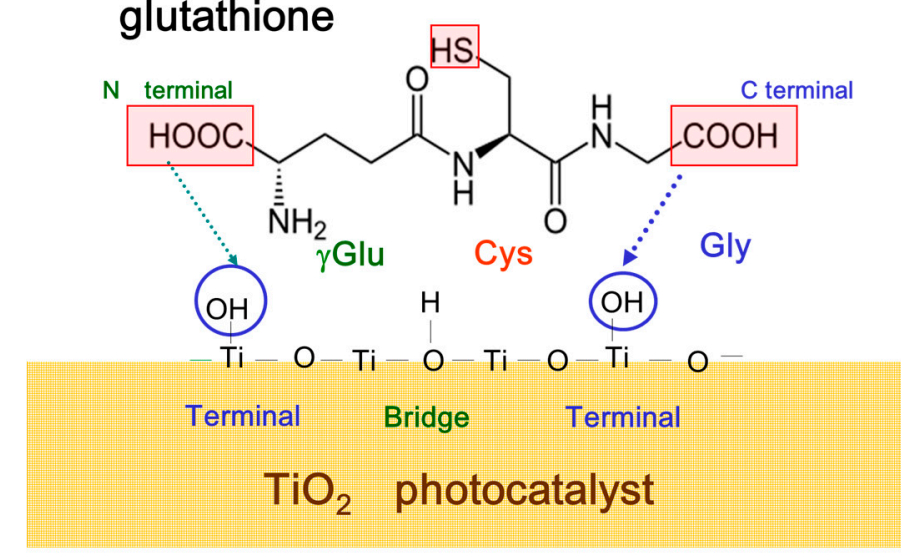

B

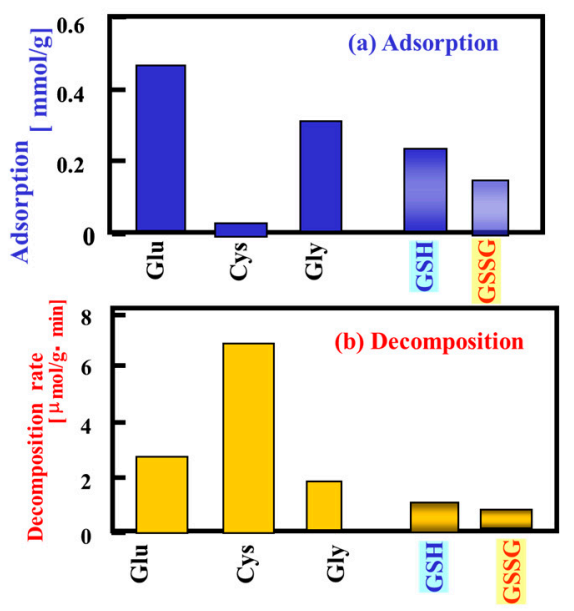


Scheme 1. Glutathione cycle.<smiles>N[C@@H](CCC(=O)NC(CS)C(=O)NCC(=O)O)C(=O)O</smiles>

GSH

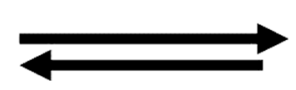

GSSG

\section{Conclusions}

$\mathrm{TiO}_{2}$ photocatalysts have been utilized for the oxidation of organic pollutants. For the development of further practical applications, the improvement of the activity with the aid of an understanding of the detailed mechanism(s) of action is a prerequisite. The primary process of photocatalysis reported in the literatures still have some confusion. To clarify the reaction mechanism, the proper and reliable detection of primary active species, such as trapped electrons, trapped holes, $\cdot \mathrm{O}_{2}{ }^{-}$and $\bullet \mathrm{OH}$, in photocatalytic systems is required. By employing various spectroscopic techniques we have succeeded in elucidating some of the mechanisms of important photocatalytic reactions. Further investigations are proceeding in our laboratory.

\section{Author Contributions}

Main contributions of each author follow; Yoshio Nosaka; Sections 2.2, 2.3, 3.1, 3.1.3, 3.2.1, Masami Nishikawa; Sections 2.1, 3.1.1, 3.1.2, and Atsuko Y. Nosaka; Sections 2.4, 3.2.2, 3.2.3. All of the authors participated in the revision and corrections of the manuscript.

\section{Conflicts of Interest}

The authors declare no conflict of interest.

\section{References}

1. Kaneko, M., Ohkura, I., Eds. Photocatalysis Science and Technology; Kodansha Ltd.: Tokyo, Japan; Springer: New York, NY, USA, 2002.

2. Anpo, M.; Kamat, P.V. (Eds.) Environmentally Benign Photocatalysts: Applications of Titanium Oxide-Based Materials; Springer: New York, NY, USA, 2010.

3. Pichat, P. (Ed.) Photocatalysis and Water Purification: From Fundamentals to Recent Applications; Wiley-VCH: Weinheim, Germany, 2013.

4. Fujishima, A.; Zhang, X.; Tryk, D.A. $\mathrm{TiO}_{2}$ Photocatalysis and related surface phenomena. Surf. Sci. Rep. 2008, 63, 515-582.

5. Henderson, M.A. A surface science perspective on $\mathrm{TiO}_{2}$ photocatalysis. Surf. Sci. Rep. 2011, 66, 185-297. 
6. Nosaka, Y.; Nosaka, A.Y. Identification and roles of the active species generated on various photocatalysts. In Photocatalysis and Water Purification; Pichat, P., Ed.; Wiley-VCH: Weinheim, Germany, 2013; pp. 3-24.

7. Nosaka, Y.; Yamashita, Y.; Fukuyama, H. Application of chemiluminescent probe to monitoring superoxide radicals and hydrogen peroxide in $\mathrm{TiO}_{2}$ photocatalysis. J. Phys. Chem. B 1997, 101, 5822-5827.

8. Koizumi, Y.; Nosaka, Y. Kinetics simulation of luminol chemiluminescence based on quantitative analysis of photons generated in electrochemical oxidation. J. Phys. Chem. A 2013, 117, $7705-7711$.

9. Hirakawa, T.; Nosaka, Y. Selective production of superoxide ions and hydrogen peroxide over nitrogen- and sulfur-doped $\mathrm{TiO}_{2}$ photocatalysts with visible light in aqueous suspension systems. J. Phys. Chem. C 2008, 112, 15818-15823.

10. Oguma, J.; Kakuma, Y.; Murayama, S.; Nosaka, Y. Effects of silica coating on photocatalytic reactions of anatase titanium dioxide studied by quantitative detection of reactive oxygen species. Appl. Catal. B 2013, 129, 282-286.

11. Nosaka, Y.; Komori, S.; Yawata, K.; Hirakawa, T.; Nosaka, A.Y. Photocatalytic •OH radical formation in $\mathrm{TiO}_{2}$ aqueous suspension studied by several detection methods. Phys. Chem. Chem. Phys. 2003, 5, 4731-4735.

12. Louit, G.; Foley, S.; Cabillac, J.; Coffigny, H.; Taran, F.; Valleix, A.; Renault, J.P.; Pin, S. The reaction of coumarin with the $\mathrm{OH}$ radical revisited: Hydroxylation product analysis determined by fluorescence and chromatography. Radiat. Phys. Chem. 2005, 72, 119-124.

13. Gerald, L.N.; Jamie, R.M. Fluorescence detection of hydroxyl radicals. Radiat. Phys. Chem. 2006, 75, 473-478.

14. Matsushita, M.; Tran, H.; Nosaka, A.Y.; Nosaka, Y. Photo-oxidation mechanism of L-alanine in $\mathrm{TiO}_{2}$ photocatalytic systems. Catal. Today 2007, 120, 240-244.

15. Nosaka, A.Y.; Nishino, J.; Fujiwara, T.; Yagi, H.; Akutsu, H.; Nosaka, Y. Effects of thermal treatments on the recovery of adsorbed water and photocatalytic activities of $\mathrm{TiO}_{2}$ photocatalytic systems. J. Phys. Chem. B 2006, 110, 8380-8385.

16. Maldotti, A.; Molinari, A.; Amadelli, R. Photocatalysis with organized systems for the oxofunctionalization of hydrocarbons by $\mathrm{O}_{2}$. Chem. Rev. 2002, 102, 3811-3836.

17. Ikeda, K.; Sakai, H.; Ryo, R.; Hashimoto, K.; Fujishima, A. Photocatalytic reactions involving radical chain reactions using microelectrodes. J. Phys. Chem. B 1997, 101, 2617-2620.

18. Zhang, J.; Nosaka, Y. Quantitative detection of $\mathrm{OH}$ radicals for investigating the reaction mechanism of various visible-light $\mathrm{TiO}_{2}$ photocatalysts in aqueous suspension. J. Phys. Chem. C 2013, 117, 1383-1391.

19. Irie, H.; Miura, S.; Kamiya, K.; Hashimoto, K. Efficient visible light-sensitive photocatalysts: Grafting $\mathrm{Cu}(\mathrm{II})$ ions onto $\mathrm{TiO}_{2}$ and $\mathrm{WO}_{3}$ photocatalysts. Chem. Phys. Lett. 2008, 457, 202-205.

20. Yu, H.; Irie, H.; Shimodaira, Y.; Hosogi, Y.; Kuroda, Y.; Miyauchi, M.; Hashimoto, K. An efficient visible-light-sensitive $\mathrm{Fe}(\mathrm{III})$-grafted $\mathrm{TiO}_{2}$ photocatalyst. J. Phys. Chem. C 2010, 114, 16481-16487.

21. Macyk, W.; Kisch, H. Photosensitization of crystalline and amorphous titanium dioxide by platinum(IV) chloride surface complexes. Chem. Eur. J. 2001, 7, 1862-1867. 
22. Ishibai, Y.; Sato, J.; Nishikawa, T.; Miyagishi, S. Synthesis of visible-light active $\mathrm{TiO}_{2}$ photocatalyst with Pt-modification: Role of $\mathrm{TiO}_{2}$ substrate for high photocatalytic activity. Appl. Catal. B 2008, 79, 117-121.

23. Nishikawa, M.; Hiura, S.; Mitani, Y.; Nosaka, Y. Photocatalytic reaction mechanism of Fe(III)-grafted $\mathrm{TiO}_{2}$ studied by means of ESR spectroscopy and chemiluminescence photometry. J. Phys. Chem. C 2012, 116, 14900-14907.

24. Nosaka, Y.; Takahashi, S.; Sakamoto, H.; Nosaka, A.Y. Reaction mechanism of Cu(II)-grafted visible-light responsive $\mathrm{TiO}_{2}$ and $\mathrm{WO}_{3}$ photocatalysts studied by means of ESR spectroscopy and chemiluminescence photometry. J. Phys. Chem. C 2011, 115, 21283-21290.

25. Nishikawa, M.; Takanami, R.; Nakagoshi, F.; Suizu, H.; Nagai, H.; Nosaka, Y. Dominated factors for high performance of $\mathrm{Fe}^{3+}$ grafted metal doped $\mathrm{TiO}_{2}$ based photocatalyst. Appl. Catal. B 2014, 160-161, 722-729.

26. Niishiro, R.; Konta, R.; Kato, H.; Chun, W.J.; Asakura, K.; Kudo, A. Photocatalytic $\mathrm{O}_{2}$ evolution of rhodium and antimony-codoped rutile-type $\mathrm{TiO}_{2}$ under visible light irradiation. J. Phys. Chem. C 2007, 111, 17420-17426.

27. Oropeza, F.E.; Egdell, R.G. Control of valence states in Rh-doped $\mathrm{TiO}_{2}$ by $\mathrm{Sb}$ co-doping: A study by high resolution X-ray photoemission spectroscopy. Chem. Phys. Lett. 2011, 515, 249-253.

28. Liu, M.; Qiu, X.; Miyauchi, M.; Hashimoto, K. Energy-level matching of Fe(III) ions grafted at surface and doped in bulk for efficient visible-light photocatalysts. J. Am. Chem. Soc. 2013, 135, 10064-10072.

29. Burgeth, G.; Kisch, H. Photocatalytic and photoelectrochemical properties of titania-chloroplatinate(IV). Coord. Chem. Rev. 2002, 230, 41-47.

30. Nishikawa, M.; Sakamoto, H.; Nosaka, Y. Reinvestigation of photocatalytic reaction mechanism for Pt-complex-modified $\mathrm{TiO}_{2}$ under visible-light irradiation by means of ESR Spectroscopy and chemiluminescence photometry. J. Phys. Chem. A 2012, 116, 9674-9679.

31. Bard, A.J.; Parsons, R.; Jordan, J. (Eds.) Standard Potentials in Aqueous Solution; Marcel Dekker: New York, NY, USA, 1985.

32. Fujishima, A.; Honda, K. Electrochemical photolysis of water at a semiconductor electrode. Nature 1972, 238, 37-38.

33. Nakabayashi, Y.; Nosaka, Y. OH radical formation at distinct faces of rutile $\mathrm{TiO}_{2}$ crystal in the procedure of photoelectrochemical water oxidation. J. Phys. Chem. C 2013, 117, 23832-23839.

34. Imanishi, A; Fukui, K. Atomic-scale surface local structure of $\mathrm{TiO}_{2}$ and its influence on the water photooxidation process. J. Phys. Chem. Lett. 2014, 5, 2108-2117.

35. Ohno, T.; Sarukawa, K.; Matsumura, M. photocatalytic activities of pure rutile particles isolated from $\mathrm{TiO}_{2}$ powder by dissolving the anatase component in HF Solution. J. Phys. Chem. B 2001, 105, 2417-2420.

36. Zhang, J.; Nosaka, Y. Mechanism of the $\mathrm{OH}$ radical generation in photocatalysis with $\mathrm{TiO}_{2}$ of different crystalline types. J. Phys. Chem. C 2014, 118, 10824-10832.

37. Hirakawa, T.; Yawata, K.; Nosaka, Y. Photocatalytic reactivity for $\mathrm{O}_{2}{ }^{-}$and $\mathrm{OH}$ radical formation in anatase and rutile $\mathrm{TiO}_{2}$ suspension as the effect of $\mathrm{H}_{2} \mathrm{O}_{2}$ addition. Appl. Catal. A 2007, 325, 105-111. 
38. Dadjour, M.F.; Ogino, C.; Matsumura, S.; Nakamura, S.; Shimizu, N. Disinfection of legionella pneumophila by ultrasonic treatment with $\mathrm{TiO}_{2}$. Water Res. 2006, 40, 1137-1142.

39. Ishiguro, H.; Nakano, R.; Yao, Y.; Kajioka, A.; Fujishima, A.; Sunada, K.; Minoshima, M.; Hashimoto, K.; Kubota, Y. Inactivation of $\mathrm{Q} \beta$ bacteriophage by photocatalysis using $\mathrm{TiO}_{2}$ thin film under weak with long wavelength UV irradiation. Photochem. Photobiol. Sci. 2011, 10, 1825-1829.

40. Diebold, U. The surface science of titanium dioxide. Surf. Sci. Rep. 2003, 48, 53-229.

41. Mastikhin, V.M.; Mudrakovsky, I.L.; Nosov, A.V. ${ }^{1}$ H-NMR magic angle spinning (MAS) studies of heterogeneous catalysis. Prog. NMR Spectrosc. 1991, 23, 259-299.

42. Köppen, S.; Bronkalla, O.; Langel, W. Molecular simulation of protein-surface interactions. J. Phys. Chem. C 2008, 112, 13600-13606.

43. Nosaka, A.Y.; Tanaka, G.; Nosaka, Y. Study by use of ${ }^{1} \mathrm{H}-\mathrm{NMR}$ spectroscopy of the adsorption and decompoaition of glycine, leucine, and derivatives in $\mathrm{TiO}_{2}$ photocatalysis. J. Phys. Chem. B 2014, 118, 7561-7567.

44. Fenoglio, I.; Greco, G.; Livraghi, S.; Fubini, B. Non-UV-induced radical reactions at the surface of $\mathrm{TiO}_{2}$ nanoparticles that may trigger toxic responses. Chem. Eur. J. 2009, 15, 4614-4621.

45. Petković, J.; Žegura, B.; Filipič, M. Influence of $\mathrm{TiO}_{2}$ nanoparticles on cellular antioxidant defense and its involvement in genotoxicity in HepG2 cells. J. Phys. Conf. Ser. 2011, 304, 1-8.

46. Horie, M.; Kato, H.; Fujita, K.; Endoh, S.; Iwahashi, H. In vitro evaluation of cellular response induced by manufactured nanoparticles. Chem. Res. Toxicol. 2012, 25, 605-619.

47. Nosaka, A.Y.; Tanaka, G.; Nosaka, Y. The behaviors of glutathione and related Amino Acids in $\mathrm{TiO}_{2}$ photocatalytic system. J. Phys. Chem. B 2012, 116, 11098-11102.

(C) 2014 by the authors; licensee MDPI, Basel, Switzerland. This article is an open access article distributed under the terms and conditions of the Creative Commons Attribution license (http://creativecommons.org/licenses/by/4.0/). 